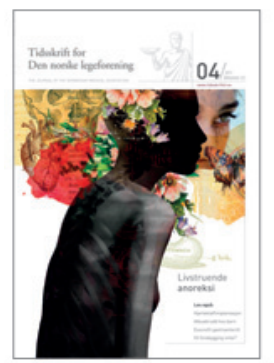

\section{Noe å lære av - noe å lære mer av?}

I Tidsskriftet nr. 4/2011 omtales en kvinne med anoreksi, hypokalemi og kramper (1). Pasienten hadde hatt langvarige brekninger, kroppsmasseindeks på $14 \mathrm{~kg} / \mathrm{m}^{2}$, serumkaliumnivå på $1,7 \mathrm{mmol} / \mathrm{l}$ og krampeanfall som ikke lot seg stoppe med diazepam. Forfatterene vektlegger hypokalemi, uten at det er opplyst om serumverdier for $\mathrm{Ca}, \mathrm{Mg}$, fosfor, tiamindifosfat eller urinutskilling av elektrolytter, selv om disse kunne bidratt til forståelsen av sykdomsbildet. Det er i det hele tatt uklart om disse undersøkelsene bare er utelatt fra fremstillingen eller om de overhodet er gjort.

Redusert s-Mg er vanlig ved hypokalemi. Hypomagnesemi kan bidra til å vedlikeholde hypokalemi, gi supra- og infraventrikulære arytmier, torsades de pointes, senke krampeterskelen og bidra til hypokalsemi pga. nedsatt PTH-sekresjon og nedsatt PTH-reseptorsensitivitet $(2,3)$.

Forfatterne omtaler realimenteringssyndrom, men angir ingen fosfatverdi (verdien går ned under dette syndromet). Fosfatverdier under $0,45 \mathrm{mmol} / 1$ anser vi som en øyeblikkelig hjelp-situasjon. Hypofosfatemien kan gi endret oksygentransport, kardiomyopati, krampetendens og besvissthetsendringer (4), som denne pasienten hadde.

Hun hadde langvarige brekninger. Det er velkjent at pasienter med brekninger under svangerskap og overvektspasienter den første tiden etter operasjon (5) kan utvikle Wernickes encefalopati pga. vitamin $\mathrm{B}_{1^{-}}$ mangel (tiaminmangel). Tiaminstatus karakteriseres best ved måling av tiamin og tiamindifosfat (6). Pasienten hadde også fått glukose intravenøst uten at den var tilsatt tiamin, noe som kan ha utløst sykdomsbildet Wernickes syndrom. Dette syndromet kan i tillegg til den klassiske triade opptre med uspesifikke symptomer. Tiaminmangelen forsterkes av samtidig Mg-mangel fordi danningen av det aktive intracellulære kompleks av tiamin er avhengig av magnesium.

I tillegg til de sannsynlige spesifikke mangeltilstander hadde pasienten en uttalt malnutrisjon, med BMI $14 \mathrm{~m} / \mathrm{kg}^{2}$, noe som rammer tverrstripet muskulatur, men også hjertemuskulatur, med derav følgende kardiomyopati.

I lys av ovenstående burde pasienten ha blitt tvangsinnlagt langt tidligere for å sikre realimentering. Serumnivå av magnesium, tiamin og fosfat burde vært kartlagt, og disse stoffene eventuelt tilført intravenøst om nødvendig gjentatte ganger.

\section{Thomas Bøhmer \\ Erik Fink Eriksen \\ Oslo}

Thomas Bøhmer (f. 1936) er professor emeritus i klinisk ernæring, fagmedisinsk ansvarlig ved Ernæringslaboratoriet, Oslo universitetssykehus, Aker

Ingen oppgitte interessekonflikter.

Erik Fink Eriksen (født 1953) er seksjonsoverlege ved endokrinologisk avdeling ved Oslo universitetssykehus, Aker og professor II ved Institutt for klinisk medisin, Universitetet i Oslo. Ingen oppgitte interessekonflikter.

\section{Litteratur}

1. Stokke A, Julsrud J, Fosse A et al. En kvinne i 20årene med anoreksi, hypokalemi og kramper. Tidsskrift Nor Legeforen 2011; 131: 358-61.

2. Bøhmer T. Magnesiummangel. En underdiagnostisert tilstand? Tidsskr Nor Lægeforen 1986; 106 $551-3$

3. Bøhmer T. Magnesiummangel. En klinisk oversikt. Tidsskr Nor Lægeforen 1986; 106: 548-51.

4. Haukeland JW, Bøhmer T. Alvorlig hypofosfatemi en oversett tilstand? Tidsskr Nor Lægeforen 1999 119: 538-40.

5. Aasheim ET. Wernicke encephalopathy after bariatric surgery: a systematic review. Ann Surg 2008; 248: $714-20$.

6. Tallaksen CM, Bell H, Bøhmer T. Thiamin and thiamin phosphate ester deficiency assessed by high performance liquid chromatography in four clinical cases of Wernicke encephalopathy. Alcohol Clin Exp Res 1993; 17: 712-6.

\section{Arne Stokke}

\section{og medarbeidere svarer:}

Bøhmer \& Fink Eriksen kommer med interessante kommentarer og tilleggsopplysninger angående vår omtalte pasient med anoreksi, hypokalemi og kramper. Ett av våre hovedpoenger var å belyse hvor farlig hypokalemi kan være (hos anorektikere) og hvordan $\mathrm{pH}$ og ventilasjon påvirker kaliumverdiene. Man kunne ønsket seg mer plass til å utdype en del av blodprøvene, men fremstillingen ble valgt slik den ble ut fra forsøket på å tydeliggjøre mekanismene i en ellers vanskelig fysiologi.

Når det gjelder s-Ca - pasienten kom inn til sykehuset i Bodø kl 0845. Vår første verdi for $\mathrm{s}-\mathrm{Ca}$ er registrert på laboratoriet $\mathrm{kl}$ 0940, den var da 2,08 $\mathrm{mmol} / 1 \mathrm{l}(2,15-2,55$ mmol/l). På samme tidspunkt (kl 0940) var $\mathrm{pH}$ redusert til 7,46, fra innkomstverdi $\mathrm{kl}$ 0850 7,84, og K-nivået økt fra 2,0 mmol/1 (kl 0912) til 3,1 mmol/1 (kl 0940). Det var frem til første Ca-verdi ble tatt ikke blitt gitt tilskudd av kalsium.

Hva gjelder magnesium, hadde vi en normal verdi for denne ved innkomst lokalsykehus kl 0608 på $0,78 \mathrm{mmol} / 1$ (samtidig $\mathrm{K} 1,7 \mathrm{mmol} / \mathrm{l})$, og den antas derfor ikke å ha spilt noen større rolle.

Hva gjelder fosfat, var første verdi kl $09400,93 \mathrm{mmol} / \mathrm{l}(0,85-1,50 \mathrm{mmol} / \mathrm{l})$. Hun fikk også tilskudd av fosfat videre i sykdomsforløpet. Tiamin ble gitt like etter innkomst i Bodø etter at krampene var stabilisert med normalisering av K-nivået. Det ble ikke målt serumnivå av tiamin før injeksjonen. Urin etter innkomst viste U-Na 14 $\mathrm{mmol} / \mathrm{l}$ og U-K $61 \mathrm{mmol} / \mathrm{l}$.

Pasientens arytmier ble stabilisert etter normalisering av kaliumnivået, noe som trekker i retning av dette som viktigste faktor. Vi er ellers enige med Bøhmer \& Fink Eriksen i at tvangsinnleggelse for realimentering er noe som tidlig må vurderes for pasienter med disse problemene.

\section{Arne Stokke}

Bodø

Joar Julsrud

Tromsø

Anette Fosse

Mo i Rana

\section{Erik Waage Nielsen}

Bodø

Arne Stokke (f. 1971) er spesialist

i barnesykdommer.

Ingen oppgitte interessekonflikter.

Joar Julsrud (f. 1950) er overlege og spesialist $\mathrm{i}$ indremedisin og i nyresykdommer. Ingen oppgitte interessekonflikter.

Anette Fosse (f. 1962) er spesialist i allmennmedisin.

Ingen oppgitte interessekonflikter.

Erik Waage Nielsen (f. 1956) er overlege og spesialist i anestesiologi.

Ingen oppgitte interessekonflikter. 